JOURNAL OF SECURITY AND SUSTAINABILITY ISSUES

ISSN 2029-7017 print/ISSN 2029-7025 online

2020 March Volume 9 Number 3

https://doi.org/10.9770/jssi.2020.9.3(26)

Scopus

\title{
THE EFFECT OF BOARD EFFECTIVENESS AND INDEPENDENCE ON THE NARRATION OF GREENHOUSE GASES (GHG) EMISSIONS DISCLOSURE
}

\author{
Mohammad Nasih", Khusnul Prasetyo ${ }^{2 *}$, Ekanto Ardi Ramadhan ${ }^{3}$, \\ Tubagus Algan Roiston ${ }^{4}$, Eka Sari Ayuningtyas ${ }^{5}$ \\ 1,2,3,4,5 Department of Accountancy, Faculty of Economics and Business, Universitas Airlangga, Indonesia \\ E-mail: ${ }^{2 *} k$ husnul.prasetyo@feb.unair.ac.id
}

Received 27 March 2019; accepted 10 January 2020; published 30 March 2020

\begin{abstract}
This research presents factors related to narration of GHG emissions disclosure in Indonesia. This phenomenon is important since in the era of advanced information technology firms are now becoming observable to many more interests. Either direct or indirect, positive or negative contribution of it will be noticed by the management in order to keep its reputation. Studying from empirical and logical facts, this research draws 390 public companies listed in IDX and published their annual report for the period of the year 2017. GHG emission disclosure data was acquired from online software TMAILC. This research confirms some factors may support the decision to disclose. They are size of board of commissioners, their independence, and companies' sensitivity. It is also tested moderating effect of companies' sensitivity. The result shows that it is significant.
\end{abstract}

Keywords: greenhouse gasses; TMAILC; annual report; negative externality

Reference to this article should be made as follows: Nasih, M., Prasetyo, K., Ramadhan, E.A., Roiston, T.A., Ayuningtyas, E.S. 2020. The effect of board effectiveness and independence on the narration of greenhouse gases (GHG) emissions disclosure. Journal of Security and Sustainability Issues, 9(3), 1025-1037. https://doi.org/10.9770/jssi.2020.9.3(26)

JEL Classifications: Q01, L25.

\section{Introduction}

Corporate accountability problems have resulted in the emergence of various efforts that encourage corporate transparency. This effort is useful to discover how firm be responsible of their activity. The element of external cost is one of measure which is aimed by corporate accountability and transparency. External costs cause symptoms of externalities, which means that the company's business activities indirectly affect the environment and the community. This illustration can be developed from the concept of marginal social cost because negative externalities arise as a result of unconsidered cost (Hyman, 2009). The global scale of concern for externalities in the environment began to materialize in the 90s. In 1992, the members of United Nation initiate a documentation of carbon emissions (now called as the six elements that trigger the effects of greenhouse gases). The initiative is based on attention to the issue of global warming, as well as the notion that carbon emissions (later GHG) from human activities are the leading cause of global warming. Quoted from un.org, the motivation of Earth Summit was " to halt the destruction of irreplaceable natural resources and pollution of the planet " by paying attention to the excessive consumption patterns which also threatened the preservation of the environment. The Earth Summit targets companies and governments to follow eco-efficient production principles.

Indonesia as a country participating in the signing of the UNFCCC framework (United Nations Framework Convention on Climate Change) are actively participated in reducing emissions on the basis of the "national goals of the Republic of Indonesia" as considered in the Law of the Republic of Indonesia no. 16 of 2016. 
Points of consideration for the Law of the Republic of Indonesia no. 6 of 1994 states that Indonesia is as "a large absorber greenhouse gases". Consistent with this statement, Law of the Republic of Indonesia no. 17 of 2004 states in its consideration that "Indonesia has an important role in influencing the climate of the earth." The same regulation also considers that as an archipelagic country, "Indonesia is very vulnerable to the impacts of climate change." benefits for Indonesia in global warming as mentioned by the points of consideration of the Law of the Republic of Indonesia no. 17 of 2004 as the potential for developing "clean technology industries".

Public companies listed on the Indonesia Stock Exchange are subject to the regulations of the Financial Services Authority as regulators and supervisors of financial service sector activities, including the capital market. Therefore, company have another focus besides economic motives, which is adhering to regulations related to company activities and capital in carrying out fiduciary duty (Ais, 2001). A principle of good corporate governance (GCG) must be fulfilled to show the company's good faith in establishing communication with outside parties about the extent to which the company's liability can be known. In addition to give positive impact on the company's business continuity, adequate accountability also benefits the community and the environment. These benefits can be realized in the form of financial or environmental maintenance which can support the quality of life of many people. Several studies have been conducted to support the idea that public companies in Indonesia have more motivation to control externalities and report them. Positive constructs on the contribution of reporting externalities in evaluating the company empirically are proven through research by Anggraeni (2015). While the internal motivation of public companies in improving the quality of reporting (Nasution \& Adhariani, 2016; Solikhah \& Winarsih, 2016), increases the scope of reporting (Cahyaningsih \& Martina, 2011), and supports comparability of reporting (Frendy \& Kusuma, 2011; Narkunienè, Ulbinaitè, 2018; Subačienè et al., 2018), which is considered still problematic (Amel-Zadeh \& Serafeim, 2017) have also supported the idea from the perspective of corporate stakeholders' management and to a certain extent, the GCG mechanism.

\section{Literature Review}

\subsection{Non-Financial Information Disclosure}

The company has social responsibility it has ability to make decisions that affect society (Isa, 2012). The conceptualization of social responsibility begins by knowing the existence of a company relationship with the general public in implementing social responsibility. After that various discussions emerged that CSR has an ethical and economic foundation that involves the demands of stakeholders and social needs. CSR is also an essential discussion in terms of marketing and corporate communication in terms of community marketing (societal marketing). Some public perceptions and companies in developing countries (Malaysia) regard CSR as a long-term commitment and require the role of the government as a regulator to encourage CSR activities. (Isa, 2012) outlines the various literacy reviews that CSR exceeds the traditional part of the company and involves organizational accountability, as Bowen calls it a "socially responsible businessman".

The demands of accountability from both internal and external stakeholders require both financial and nonfinancial information. Bonsón \& Bednárová (2015), Mayorova (2019) compiled several reasons for CSR reporting including: showing a sense of responsibility, meeting stakeholder expectations and contributing to society, managing the legitimacy of the company, maintaining reputation and identity, supporting stakeholder decision-making that has an impact on profitability, and reducing pressure from stakeholders. They mentioned that CSR reporting is needed to respond the attention of corporate scandals and tools to achieve sustainability (Bonsón \& Bednárová, 2015).

John Elkington (in Slaper \& Hall, 2011) popularized the triple bottom line (TBL) reporting framework that measures the performance of companies in America with a sustainable orientation. Triple (T) in TBL means companies need to report not only one bottom line but three: financial, social, and environmental performance. By using the TBL concept, companies can communicate essential aspects of company performance to stake- 
holders or the wider community.

The validation issues found by Isa (2012) are verified by a survey of investor needs regarding environmental, social, and government data. Respondents in America and Europe found that comparability, standard existence, and costs of collecting and analyzing ESG data as the main factors inhibiting ESG information values (AmelZadeh \& Serafeim, 2017). Whereas in the same study, it was found that the two main reasons investors did not consider the ESG data: lack of demand from stakeholders and lack of reliable non-financial data access. Several initiatives on an international scale have been carried out to encourage corporate accountability in supporting sustainable development. One of the focuses of this research is the management of greenhouse gas (GHG) emissions of companies that were initiated by international conventions such as the 1985 Vienna Protocol related to Ozone Layer Protection. The Montreal Amendment Protocol 1990 concerning Materials That Can Damage the Ozone Layer, Rio 1992 Convention one of which concerning the United Nations Framework on Climate Change, the 1998 Kyoto Protocol on the United Nations Framework on Climate Change, and the Paris Agreement 2016. These international agreements have been ratified into the Law of Republic Indonesia no. 32 of 2009 concerning Environmental Protection and Management and Presidential Regulation of the Republic of Indonesia no. 71 2011. This regulation concerning the Implementation of the National Greenhouse Gas Inventory, which in detail, discusses the inventory guidelines of the Intergovernmental Panel on Climate Change (IPCC). Law no. 8 of 1995 concerning Capital Market regulates the principle of openness of public companies, one of which is the environmental aspect explained by the Financial Services Authority (OJK) Circular no. 30 of 2016 concerning the Form and Content of the Annual Report of Issuers or Public Companies.

The company utilizes publications provided by international organizations such as the Global Reporting Initiative (GRI) indicator guidelines, KPMG's survey namely the International Survey of Environmental Reporting, or other indicators introduced both by the private sector and local government regulations. Razeed observed the trend of using these publications by adding criticism to the homogeneity that could be drawn from these guidelines. Razeed (2010) argues that corporate disclosures, as measured by such instructions, can encourage conservatism. Quoting Buzby (1975), Razeed states that exposure (number of scores, indices, etc.) disclosures are not proportional to the quality and adequacy of disclosures. This statement is based on the assumption of Razeed (from Wheeler \& Sillanpaa, 1998) that the key to environmental reporting is a way to build stakeholder loyalty and trust.

In line with Razeed, the company's reputation and the legitimacy of the company formed by the media in the public sphere are behind the research of Anggraeni (2015). In the study, Anggraeni examined the effects of environmental performance on firm value. Although not significant, the research is useful for finding one of the reliable sources of legitimacy, namely the government through the Ministry of Environment (now Environment and Forestry) of the Republic of Indonesia. This ranking also exposes the positive side of companies involved in public space through media publications. Besides, the harmful exposure of the mass media to the operational errors of the company that impacted the catastrophe encouraged companies in specific industrial sectors to provide relevant information that could explain the company's attention to the issue.

An example is Suaryana (2011) who gives attention to the urgency of social and environmental accounting for the threat of environmental pollution by mining exploitation activities covered by the media. This study uses the disclosure of greenhouse gases (GHGs) or GHG greenhouse gases as reporting on non-financial information of the company. As an issue that has received attention for a long time (since the ratification of Kyoto Protocol in 1992), the disclosure of GHG emissions has received recognition from researchers and also companies. And the treatment of the United Nations with the IPCC which raised the issue to the realm of international politics caused Indonesia to ratify the guidelines issued into the Act and its explanations. An open company is required to implement and disclose good governance practices following international practices that are exemplary, as required by OJK Regulation no. 21 of 2015 . One of the global practices that can be used as an example is the OECD guidelines which read "The rights of stakeholders that are established by law are to be respected." However, the same OJK regulations also reduce pressure with limitations for companies with specific complexity, industry type, and size. 


\subsection{Hypothesis Development}

This study uses the size and independence of company's board separately to determine corporate governance in the disclosure of greenhouse gases. As the previous study shows that there is a relationship exist between firm disclosure, especially for environmental disclosure to the corporate governance characteristics (Nasih et al., 2019). The size of the board of directors will be proportional to the level of control that drives transparency. This opinion is in line with one of the views of literature on stakeholders, namely the relationship of risk status compiled by Mitchell et al. (1997). Independence is needed when companies are faced with the demands of transparency from many parties, so that information asymmetry is reduced (Goh et al. 2016) and to minimize conflicts of interest through independent decisions on essential company policies. While several other parameters, namely the type of industry, company size, company profitability, and company capital structure included in the study as another explanation. So the role of managers is maintaining the company's essential policies, accommodate the interests of the shareholders, and preserve the environment by conveying the company's openness to the greenhouse effect produced. According to Widyadmono (2014) it does not rule out the possibility that a large board size will increase the debt structure that is owned accompanied by an obligation to fulfill environmental compliance. But Elfeky (2017) believes that commitment to the environment and society is very essential to show the company's commitment. For this description, this study proposes the following hypothesis:

\section{H1: The number of directors has a significant positive effect on GHG reporting}

\section{H2: The level of the independence of directors has a significant positive effect on GHG reporting}

\section{H3: The number of commissioners has a significant positive effect on GHG reporting}

H4: The measure of the independence of the board of commissioners has a significant positive effect on GHG reporting

H5: The size of the audit committee has a significant positive effect on GHG reporting

H6: The sensitivity of the company has a significant positive effect on GHG reporting

H7: The company sensitivity significantly modifies the influence of H1 - H5

\section{Research Methodology}

\subsection{Sample Selection}

This study attempts to predict the parameters studied for public companies listed on the Indonesia Stock Exchange. To limit the extent of the variables under investigation, only public companies are listed in the annex of the IDX fact book 2017 and publish annual reports for 2017. The selection of companies as samples is complemented by confirming issuers with delisting companies with new issuers and issuers. This process has produced 390 sample units of companies with sufficient data. This study attempts to predict the parameters studied for public companies listed on the Indonesia Stock Exchange. To limit the extent of the variables under investigation, only public companies are listed in the annex of the IDX fact book 2017 and publish annual reports for 2017. The selection of companies as samples is complemented by confirming issuers with delisting companies with new issuers and issuers. This process has produced 390 sample units of companies with sufficient data.

\subsection{Variables Measurement}

\section{GHGDISC}

a. Meaning (type): number of narratives for disclosure of greenhouse gas (bound)

b. Measurement: the number of narratives related to greenhouse gases found with an infinite 0 - positive scale 
c. Explanation: this variable was found with the help of TMAILC (Text Mining Analysis Indonesian Listed Company) online software. The calculated narrative is a narrative that contains the following keywords: greenhouse, climate change, global warming, $\mathrm{CO} 2$, carbon, methane, $\mathrm{CH} 4$, nitrous oxide, $\mathrm{N} 2 \mathrm{O}$, chlorofluorocarbon, CFC, SF6, and NF3. These keywords are developed from a list of GHG emissions that need to be inventoried by the UNFCCC (CO2, CH4, N2O, HFCs, PFCs, SF6, and NF3). Only the specified keywords can be obtained.

\section{DIRSIZE}

a. Meaning (type): number of company directors (free)

b. Measurement: the number of people who occupy directors' positions in companies with a 0 - positive scale is infinite

c. Explanation: this variable is obtained from secondary data. Variables other than COMMSIZE that describe a measure of performance effectiveness in corporate governance.

\section{INDDIR}

a. Meaning (type): number of independent or unaffiliated company directors (free)

b. Measurement: the number of people occupying independent directors with an infinite scale of 0 - positive

c. Explanation: this variable is obtained from secondary data. Variables other than INDCOMM and AUDCOMM that describe independence in corporate governance.

\section{COMMSIZE}

a. Meaning (type): number of company commissioners (free)

b. Measurement: the number of people who occupy directors' positions in companies with a 0 - positive scale is infinite

c. Explanation: this variable is obtained from secondary data. Variables other than DIRSIZE that describe measures of effectiveness in corporate governance.

\section{INDCOMM}

a. Meaning (type): number of independent commissioners of the company (free)

b. Measurement: the number of people who occupy the position of independent commissioners with a scale of 0 - positive is infinite

c. Explanation: this variable is obtained from secondary data. Variables other than INDDIR and AUDCOMM that describe independence in corporate governance.

\section{AUDCOMM}

a. Meaning (type): number of members of the company audit committee (free)

b. Measurement: the number of people who occupy the position of audit committee members with a 0 - positive scale is infinite

c. Explanation: this variable is obtained from secondary data. Variables other than INDDIR and INDCOMM that describe independence in corporate governance.

\section{SENS}

a. Meaning (type): sensitivity to GHG problems (free, moderating)

b. Measurement: assessment of the company's sensitivity to GHG issues with binary scales 0 and 1

c. Explanation: this variable is obtained from secondary data. Value 1 means that the company has special attention to GHG issues within the company's operational scope. Conversely, a value of 0 means that the company does not have that concern. This assessment is based on research referred to, namely the type of industry based on SIC (Standard Industrial Classification). Industrial code with number 0, d. 3 is given a value of 1 while the other is given a value of 0 .

\section{SIZE}

a. Meaning (type): company size (free, control)

b. Measurement: the natural logarithm of the monetary value of the total assets of a company with a scale of 0 - positive is infinite

c. Explanation: this variable is obtained from secondary data. Variables other than PROF and LEV which become control variables in the regression model are proposed. 


\section{PROF}

a. Meaning (type): company profitability (free, control)

b. Measurement: the ratio of the company's net profit to the total assets of a company with the scale of all real numbers

c. Explanation: this variable is obtained from secondary data. Variables other than SIZE and LEV which become control variables in the regression model are proposed.

\section{LEV}

a. Meaning (type): company capital structure (free, control)

b. Measurement: the ratio of total liabilities to total equity of a company with an infinite scale of 0 - positive

Explanation: this variable is obtained from secondary data. Variables other than SIZE and PROF are the control variables in the regression model proposed.

\subsection{Specification Model}

Based on the hypothesis proposed, this study uses one dependent variable GHGDISC, six independent variables: DIRSIZE, INDDIR, COMMSIZE, INDCOMM, AUDCOMM and SENS, and three control variables developed from the research referred to SIZE, PROF, LEV. So, to prove the H1 hypothesis d. H5 is proposed by the following multivariable linear regression model (then called Model 1):

GHGDISC $=\alpha+\beta_{1}$ DIRSIZE $+\beta_{2}$ INDDIR $+\beta_{3}$ COMMSIZE $+\beta_{4}$ INDCOMM $+\beta_{5}$ AUDCOMM + $\beta_{6} \mathrm{SIZE}+\beta_{7} \mathrm{PROF}+\beta_{8} \mathrm{LEV}+\varepsilon$

Whereas, to prove the hypothesis $\mathrm{H} 1 \mathrm{~d}$. $\mathrm{H} 5$ and $\mathrm{H} 6$ and $\mathrm{H} 7$ are proposed by multivariable linear regression models with moderating variables (then called Model 2 s.d. Model 6) as follows:

GHGDISC $=\alpha+\beta_{1}$ DIRSIZE $+\beta_{2}$ INDDIR $+\beta_{3}$ COMMSIZE $+\beta_{4}$ INDCOMM $+\beta_{5}$ AUDCOMM + $\beta_{6}$ SENS $+\beta_{7}$ DIRSIZE $*$ SENS $+\beta_{8}$ SIZE $+\beta_{9}$ PROF $+\beta_{10} \mathrm{LEV}+\varepsilon$

GHGDISC $=\alpha+\beta_{1}$ DIRSIZE $+\beta_{2}$ INDDIR $+\beta_{3}$ COMMSIZE $+\beta_{4}$ INDCOMM $+\beta_{5}$ AUDCOMM + $\beta_{6}$ SENS $+\beta_{7}$ INDDIR $*$ SENS $+\beta_{8}$ SIZE $+\beta_{9}$ PROF $+\beta_{10}$ LEV $+\varepsilon$

GHGDISC $=\alpha+\beta_{1}$ DIRSIZE $+\beta_{2}$ INDDIR $+\beta_{3}$ COMMSIZE $+\beta_{4}$ INDCOMM $+\beta_{5}$ AUDCOMM + $\beta_{6} \mathrm{SENS}+\beta_{7} \mathrm{COMMSIZE} * \mathrm{SENS}+\beta_{8} \mathrm{SIZE}+\beta_{9} \mathrm{PROF}+\beta_{10} \mathrm{LEV}+\varepsilon$

GHGDISC $=\alpha+\beta_{1}$ DIRSIZE $+\beta_{2}$ INDDIR $+\beta_{3}$ COMMSIZE $+\beta_{4}$ INDCOMM $+\beta_{5}$ AUDCOMM + $\beta_{6} \mathrm{SENS}+\beta_{7} \mathrm{INDCOMM} * \mathrm{SENS}+\beta_{8} \mathrm{SIZE}+\beta_{9} \mathrm{PROF}+\beta_{10} \mathrm{LEV}+\varepsilon$

GHGDISC $=\alpha+\beta_{1}$ DIRSIZE $+\beta_{2}$ INDDIR $+\beta_{3}$ COMMSIZE $+\beta_{4}$ INDCOMM $+\beta_{5}$ AUDCOMM + $\beta_{6} \mathrm{SENS}+\beta_{7} \mathrm{AUDCOMM} * \mathrm{SENS}+\beta_{8} \mathrm{SIZE}+\beta_{9} \mathrm{PROF}+\beta_{10} \mathrm{LEV}+\varepsilon$

\section{Result and Discussion}

The findings of this study are that annual report data is more widely publicized by companies in sensitive industrial types ( 0 dd. 3 ) than those of insensitive industries (4 s.d. 9). PT Perusahaan Gas Negara (Persero) Tbk. (PGAS) reports the most data, which is 49 times followed by PT Indocement Tunggal Prakarsa Tbk. (INTP) which is 37 times. Both of these values have distances from the average (only for GHGDISC values greater than 1, which is 4.37) of 5.88 and 4.3 times standard deviation (7.59). The next highest value is 19 times (SGRO and ITMG), which is less than twice the standard deviation. 217 narratives were found in sensitive code companies, and half (111 narratives) in other companies. Among companies that are insensitive, companies in the transportation \& public utilities sector (code 4) provide the most findings, which are 76 findings. When compared with the average findings per industry, this sector provides the highest value with 12.67 findings per company. In general, the collective average value of 4.37 findings per company is not much different from the sectoral average value (based on sensitivity) with 4.34 for sensitive companies and 4.44 for those who do not. The difference in 
sectoral averages is caused by generally sensitive companies reporting more on GHG emissions narratives (50 companies) than those without (25). Overall, narrative data processing has found 75 companies with a minimum GHGDISC value of one, with more sensitive companies (66\% with 34\%). That amount is equal to around $19 \%$ of the total 390 samples of the company studied. From the whole sample, it can also be found that around $24 \%$ of 210 companies are sensitive and $14 \%$ of 180 companies are insensitive which have at least one GHGDISC value. This could mean two things: the company's conservatism in compliance with regulations or company commitments is not enough. Summing up from Razeed (2010) conservatism of compliance means that companies only report what they feel is necessary in a simple manner based on general guidelines that are practically used. While continuing Michelon, et al. (2015, in Nasution and Adhariani, 2016), looking at a percentage that is not much different $(28 \%, 24 \%$, and $32 \%$ separate CSR reporting numbers) the issue of commitment can also be concluded the same in this study. Cho, et al. (2012, in Nasution and Adhariani, 2016) use separate CSR reporting as a sign that the company wants to increase its accountability. The principle is in line with the purpose of processing narrative data carried out by this study. More detailed distribution of industrial data can be seen in Table 1. Meanwhile, Tables 2 and 3 each show descriptive statistics for the entire sample and sample with the narrative that was successfully found with a minimum value of one (see table 2 and table 3 for descriptive statistics).

Table 1. Sample Distribution Based on Industry Type (SIC)

\begin{tabular}{|c|c|c|c|c|c|c|c|c|c|c|}
\hline \multirow{2}{*}{ TAHUN } & \multicolumn{10}{|c|}{ SIC } \\
\hline & 0 & 1 & 2 & 3 & 4 & 5 & 6 & 7 & 8 & $\Sigma$ \\
\hline 2017 & 13 & 49 & 91 & 57 & 56 & 37 & 48 & 30 & 9 & 390 \\
\hline$\%$ & 3.33 & 12.56 & 23.33 & 14.62 & 14.36 & 9.49 & 12.31 & 7.69 & 2.31 & 100 \\
\hline Total & 13 & 49 & 91 & 57 & 56 & 37 & 48 & 30 & 9 & 390 \\
\hline$\%$ & 3.33 & 12.56 & 23.33 & 14.62 & 14.36 & 9.49 & 12.31 & 7.69 & 2.31 & 100 \\
\hline
\end{tabular}

Table 2. Descriptive Statistic $(\mathrm{n}=390)$

\begin{tabular}{|l|c|c|c|c|c|}
\hline & Mean & Median & Std. Deviation & Minimum & Maximum \\
\hline GHGDISC & 0.841 & 0.000 & 3.734 & 0.000 & 49.000 \\
\hline DIRSIZE & 4.749 & 4.000 & 1.914 & 2.000 & 14.000 \\
\hline INDDIR & 0.192 & 0.200 & 0.141 & 0.000 & 0.667 \\
\hline COMMSIZE & 4.141 & 3.500 & 1.769 & 2.000 & 12.000 \\
\hline INDCOMM & 0.379 & 0.333 & 0.120 & 0.000 & 1.000 \\
\hline AUDCOMM & 2.979 & 3.000 & 0.645 & 0.000 & 6.000 \\
\hline ROA & 4.431 & 3.960 & 12.158 & -59.620 & 70.910 \\
\hline LEV & 9.864 & 4.227 & 45.398 & 0.175 & 809.896 \\
\hline SIZE & 28.695 & 28.703 & 1.647 & 23.438 & 33.320 \\
\hline
\end{tabular}

Table 3. Descriptive Statistic $(n=75)$

\begin{tabular}{|l|c|c|c|c|c|}
\hline & Mean & Median & Std. Deviation & Minimum & Maximum \\
\hline GHGDISC & 4.37 & 2 & 7.59 & 1 & 2 \\
\hline DIRSIZE & 6.12 & 6 & 2.21 & 0 & 12 \\
\hline INDDIR & 0.14 & 0.14 & 0.11 & 2 & 0.33 \\
\hline COMMSIZE & 5.28 & 5 & 2.25 & 0 & 12 \\
\hline INDCOMM & 0.37 & 0.33 & 0.13 & 0 & 6 \\
\hline AUDCOMM & 3.11 & 3 & 0.67 & 25.8 & 33.32 \\
\hline ROA & 29.77 & 29.66 & 1.54 & -13.22 & 70.91 \\
\hline LEV & 8.78 & 5.98 & 12.4 & 3.18 & 16.9 \\
\hline SIZE & 5.16 & 4.14 & & & \\
\hline
\end{tabular}




\subsection{Correlation Analysis}

Correlation analysis aims to determine the relationship between the variables studied in samples that are found or processed individually. This study uses Pearson's product-moment as a measure of the correlation coefficient shown in the form of an i $\mathrm{x}$ i matrix, with $\mathrm{i}$ is the number of variables studied. Based on the correlation matrix table (table 4.4), it can be seen that the number of directors, the size of independent directors, the number of commissioners, and the size of the audit committee have a very significant relationship with the number of GHG emissions disclosures found. At a significance level of less than $1 \%$, the number of directors, the number of independent directors, and the number of commissioners are related to the number of disclosures of 0.197 , -0.135 , and 0.198 respectively. At the significance level of less than $5 \%$, the size of the audit committee has a relationship with the amount of disclosure of 0.125 . Firm size and profitability have a relationship as a control variable to the number of disclosures of 0.242 and 0.114 at the level of confidence of each less than $1 \%$ and less than 5\%. The capital structure and the number of independent commissioners have a relationship inversely proportional to the amount of disclosure. However, in this study, no significant relationship (more than $10 \%$ ) was found for both (see table 4).

Tabel 4. Pearson Correlation Matrix

\begin{tabular}{|c|c|c|c|c|c|c|c|c|c|}
\hline & GHGDISC & DIRSIZE & INDDIR & COMMSIZE & INDCOMM & AUDCOMM & SIZE & PROF & LEV \\
\hline GHGDISC & 1.000 & & & & & & & & \\
\hline DIRSIZE & $0.197^{* * *}$ & 1.000 & & & & & & & \\
\hline & $(0.000)$ & & & & & & & & \\
\hline INDDIR & $-0.135^{* * *}$ & $-0.390^{* * *}$ & 1.000 & & & & & & \\
\hline & $(0.007)$ & $(0.000)$ & & & & & & & \\
\hline COMMSIZE & $0.198^{* * *}$ & $0.524^{* * *}$ & $-0.198^{* * *}$ & 1.000 & & & & & \\
\hline & $(0.000)$ & $(0.000)$ & $(0.000)$ & & & & & & \\
\hline INDCOMM & -0.075 & 0.043 & $0.188^{* * *}$ & -0.007 & 1.000 & & & & \\
\hline & $(0.139)$ & $(0.402)$ & $(0.000)$ & $(0.886)$ & & & & & \\
\hline AUDCOMM & $0.125^{* *}$ & $0.214^{* * *}$ & -0.063 & $0.194^{* * *}$ & 0.041 & 1.000 & & & \\
\hline & $(0.014)$ & $(0.000)$ & $(0.214)$ & $(0.000)$ & $(0.424)$ & & & & \\
\hline SIZE & $0.242^{* * *}$ & $0.550^{* * *}$ & $-0.258^{* * *}$ & $0.529^{* * *}$ & 0.036 & $0.244^{* * *}$ & 1.000 & & \\
\hline & $(0.000)$ & $(0.000)$ & $(0.000)$ & $(0.000)$ & $(0.484)$ & $(0.000)$ & & & \\
\hline PROF & $0.114^{* *}$ & $0.218^{* * *}$ & $-0.100^{* *}$ & $0.214^{* * *}$ & 0.019 & 0.073 & $0.210^{* * *}$ & 1.000 & \\
\hline & $(0.024)$ & $(0.000)$ & $(0.048)$ & $(0.000)$ & $(0.705)$ & $(0.150)$ & $(0.000)$ & & \\
\hline LEV & -0.017 & $-0.129^{* *}$ & $0.179^{* * *}$ & -0.061 & 0.010 & -0.018 & $-0.085^{*}$ & $-0.105^{* *}$ & 1.000 \\
\hline & $(0.745)$ & $(0.011)$ & $(0.000)$ & $(0.229)$ & $(0.840)$ & $(0.728)$ & $(0.093)$ & $(0.038)$ & \\
\hline
\end{tabular}

$\mathrm{P}$-values are in parentheses, asterisks are significant in $\mathrm{P}$-values with $*=\mathrm{p}<0.1, * *=\mathrm{p}<0.05, * * *=\mathrm{p}<0.01$

The results of this analysis support the significance of four of the five initial hypotheses (H1, H2, H3, H5). This means that individually (specifically one variable) the company in the sample takes advantage of the company's organs (number of directors, number of independent directors, number of commissioners, and size of the audit committee) to pay attention to the accountability of GHG emissions issues.

\subsection{Regression Analysis}

Based on the results of data processing with STATA, the six models have a coefficient of determination that is not much different (0.103 for Model 1, d. 0.109 for Model 2). For the five hypotheses (H1 d. H5), only more $\mathrm{H} 3$ and $\mathrm{H} 4$ can be proven by five of the six regression models proposed showing significance. Table 5 shows the findings that the number of commissioners has a positive and significant effect (P-value of less than 5\%) in Models 1, 2, 3, 5 and 6 of the number of sample disclosures processed from TMAILC. The consistency of the number of commissioners regression coefficients appears on the five models. While the size of independ- 
ent commissioners was found to have a negative and significant effect (P-value less than 5\%) in Models 1, 2, 3,4 , and 6 . In addition to the strong significance, all (six) proposed models succeeded in providing inversion consistent in the form of negative regression coefficients. The level of significance of company sensitivity was found to modify the influence of four of the five corporate governance variables proposed. Although separately only being able to explain the amount of disclosure significantly in Models 3 and 4 only, the type of industry as a proxy for sensitivity of the company is able to significantly modify the influence of the number of directors, independent director size, and number of commissioners with a P-value of less than $5 \%$ in Model 2, 3, and 4. In models 5 and 6 , the sensitivity of each moderates the effect of independent commissioner size with a P-value of less than $10 \%$ and does not indicate moderation in the influence of the size of the audit committee. So that $\mathrm{H} 7$ can be proven in Models 2, 3, 4, and 5. Individually, the significance of the sensitivity effect has been found in Models 3 and 4 with a P-value of less than 5\%.

Table 5. Multivariabel Linear Regression

\begin{tabular}{|c|c|c|c|c|c|c|}
\hline \multirow[t]{2}{*}{ Variabel } & \multicolumn{6}{|c|}{ Model GHGDISC } \\
\hline & 1 & 2 & 3 & 4 & 5 & 6 \\
\hline \multirow[t]{2}{*}{ DIRSIZE } & 0.096 & -0.190 & 0.092 & 0.086 & 0.102 & 0.101 \\
\hline & $(0.63)$ & $(-1.33)$ & $(0.61)$ & $(0.58)$ & $(0.67)$ & $(0.68)$ \\
\hline \multirow[t]{2}{*}{ INDDIR } & -1.024 & -1.001 & $2.307^{*}$ & -1.125 & -0.999 & -0.890 \\
\hline & $(-0.68)$ & $(-0.67)$ & $(1.74)$ & $(-0.74)$ & $(-0.67)$ & $(-0.61)$ \\
\hline \multirow[t]{2}{*}{ COMMSIZE } & $0.159^{* *}$ & $0.159^{* *}$ & $0.165^{* *}$ & -0.082 & $0.159^{* *}$ & $0.157^{* *}$ \\
\hline & $(2.07)$ & $(2.05)$ & $(2.10)$ & $(-0.74)$ & $(2.07)$ & $(2.04)$ \\
\hline \multirow[t]{2}{*}{ INDCOMM } & $-2.539^{* *}$ & $-2.569^{* *}$ & $-2.572^{* *}$ & $-2.491^{* *}$ & -0.354 & $-2.549^{* *}$ \\
\hline & $(-2.05)$ & $(-2.08)$ & $(-2.07)$ & $(-2.04)$ & $(-0.41)$ & $(-2.04)$ \\
\hline \multirow[t]{2}{*}{ AUDCOMM } & 0.360 & 0.352 & 0.335 & 0.352 & 0.362 & -0.624 \\
\hline & $(0.65)$ & $(0.64)$ & $(0.62)$ & $(0.64)$ & $(0.66)$ & $(-1.38)$ \\
\hline \multirow[t]{2}{*}{ DIRSIZE_SENS } & & $0.356^{* *}$ & & & & \\
\hline & & $(2.03)$ & & & & \\
\hline \multirow[t]{2}{*}{ INDDIR_SENS } & & & $-4.133^{* *}$ & & & \\
\hline & & & $(-2.18)$ & & & \\
\hline \multirow[t]{2}{*}{ COMMSIZE_SENS } & & & & $0.334^{* *}$ & & \\
\hline & & & & $(1.98)$ & & \\
\hline \multirow[t]{2}{*}{ INDCOMM_SENS } & & & & & $-3.046^{*}$ & \\
\hline & & & & & $(-1.72)$ & \\
\hline \multirow[t]{2}{*}{ AUDCOMM_SENS } & & & & & & 1.201 \\
\hline & & & & & & $(1.53)$ \\
\hline \multirow[t]{2}{*}{ SENS } & & 1.057 & $3.426^{* *}$ & 1.271 & $3.796^{* *}$ & -0.967 \\
\hline & & $(0.62)$ & $(2.16)$ & $(0.76)$ & $(2.32)$ & $(-0.35)$ \\
\hline \multirow[t]{2}{*}{ CONSTANT } & -7.053 & $-8.430^{*}$ & $-10.31^{* *}$ & $-8.042^{*}$ & $-10.25^{* *}$ & $-6.674^{*}$ \\
\hline & $(-1.39)$ & $(-1.78)$ & $(-2.01)$ & $(-1.74)$ & $(-2.02)$ & $(-1.73)$ \\
\hline CONTROL & Included & Included & Included & Included & Included & Included \\
\hline $\mathrm{R}^{2}$ & 0.103 & 0.109 & 0.107 & 0.108 & 0.105 & 0.107 \\
\hline $\mathrm{N}$ & 390 & 390 & 390 & 390 & 390 & 390 \\
\hline
\end{tabular}

The $\mathrm{t}$-value is displayed in brackets, significance $*=\mathrm{p}<0.1, * *=\mathrm{p}<0.05, * * *=\mathrm{p}<0.01$

\subsection{Proof of Hypothesis}

The results of this regression analysis summarize the proof of the hypothesis after considering the significance of each regression coefficient in Table 6. 
Tabel 6. Proof of Hypothesis

\begin{tabular}{|l|l|l|l|l|l|c|}
\hline & Model 1 & Model 2 & Model 3 & Model 4 & Model 5 & Model 6 \\
\hline $\mathrm{H}_{1}$ & Rejected & Rejected & Rejected & Rejected & Rejected & Rejected \\
\hline $\mathrm{H}_{2}$ & Rejected & Rejected & Accepted & Rejected & Rejected & Rejected \\
\hline $\mathrm{H}_{3}$ & Accepted & Accepted & Accepted & Ditolak & Accepted & Accepted \\
\hline $\mathrm{H}_{4}$ & Rejected & Rejected & Rejected & Rejected & Rejected & Rejected \\
\hline $\mathrm{H}_{5}$ & Rejected & Rejected & Rejected & Rejected & Rejected & Rejected \\
\hline $\mathrm{H}_{6}$ & Tidak diteliti & Rejected & Accepted & Rejected & Accepted & Rejected \\
\hline $\mathrm{H}_{7}$ & Tidak diteliti & Diterima & Accepted & Accepted & Accepted & Rejected \\
\hline
\end{tabular}

\section{Description:}

1. H1 is tested with DIRSIZE variables on all models.

2. H2 is tested with INDDIR variables on all models.

3. H3 is tested with COMMSIZE variables on all models.

4. H4 is tested with INDCOMM variables on all models.

5. H5 is tested with the AUDCOMM variable on all models.

6. H6 is tested with the SENS variable in Model 2 d. 6.

7. $\mathrm{H} 7$ is tested by the interaction of SENS variables on the DIRSIZE, INDDIR, COMMSIZE, INDCOMM, and AUDCOMM variables on Model 2 s.d. 6.

\section{Conclusions}

This study tries to find out how the influence of the effectiveness and independence of corporate organs on the disclosure of company GHG emissions. This research is essential because non-financial information is a strategic issue in reporting company performance (Bassen \& Kovács, 2008; Luhn et al., 2017). This is important because transparency over non-financial information can reduce negative externalities in the form of uncontrolled GHG emissions. The role of the director and commissioner of the company is to manage the company to achieve various objectives. In the era of information technology sophistication, this goal is not only focused on the wealth of the company and its shareholders. However, there is involvement of the community and the government in promoting sustainable development related to efforts to control emissions (Mukhlis, 2009). From here, entrepreneurs need to apply identification and proper stakeholder management to improve reputation and maximize company value (Anggraeni, 2015), gain legitimacy (Mitchell, et al., 1997), attract new investors through the socially responsible investments mechanism (Zulkafli, et al., 2017), or to implement the altruist motive as remuneration.

The study was conducted on 390 companies listed on the Indonesia Stock Exchange in 2017. This study has undertaken a correlation test and has developed a regression model with mixed results. The results show only the number of commissioners, the size of the board of commissioners' independence, and the moderation of sensitivity that can explain the consistent significance that is on all but one proposed model. Of the three variables, only the measure of the independence of the commissioners rejects the initial hypothesis with a regression coefficient that is significant at the negative value. In this study, the effectiveness represented by the number of commissioners positively influences the disclosure of GHG emissions narratives in public companies in Indonesia for specific models according to the board size proposed by Solikhah \& Winarsih (2016) and Giannarakis (2014). Then, the independence represented by a measure of the independence of the board of commissioners negatively influences the disclosure of narrative GHG emissions in public companies in Indonesia for specific models following the results of research by Solikhah \& Winarsih (2016). The sensitivity of the company represented by the type of company industry is found to influence the disclosure of GHG emissions narratives in public companies in Indonesia for specific models following the industry profile in Frendy \& Kusuma (2011) and Hackston \& Milne (1996). And the moderation of the sensitivity of the company represented by the type of company industry was found to influence the disclosure of GHG emissions narratives in public companies in 
Indonesia for specific models. Whereas, for other variables, no significant influence was seen, which could accept the initial hypothesis. However, the regression coefficients on these variables also cannot necessarily reject the initial hypothesis. In general, variables with weak significance can be considered as findings that reject the initial hypothesis. That is, this study methodologically managed to answer the research problems as follows:

1. The effectiveness represented by the number of directors does not show a significant effect on the disclosure of public company GHG emissions narratives in Indonesia

2. The effectiveness represented by the number of commissioners shows a significant positive effect on the disclosure of narratives of GHG emissions of public companies in Indonesia in five of the six proposed analysis models

3. Independence represented by a measure of the independence of directors only shows a significant positive effect on the disclosure of narratives of GHG emissions of public companies in Indonesia in one of the six proposed analysis models

4. Independence represented by a measure of the independence of the board of commissioners shows a significant positive effect on the disclosure of narratives of GHG emissions of public companies in Indonesia in five of the six models of analysis proposed.

\section{References}

Ais, Chatamarrasjid. 2001. "Fiduciary Duty" Sebagai Standar Para Direksi Dalam Melaksanakan Tugasnya. Jurnal Hukum \& Pembangunan, 31(1), 63-72.

Anggraeni, Dian Yuni. 2015. Pengungkapan Emisi Gas Rumah Kaca, Kinerja Lingkungan, dan Nilai Perusahaan. Jurnal Akuntansi dan Keuangan Indonesia, 12(2), 188-209.

Amel-Zadeh, Amir \& George Serafeim. 2017. Why and How Investors Use ESG Information: Evidence from a Global Survey. Diakses dari https://ssrn.com/abstract=2925310

Bassen, Alexander \& Ana Maria Masha Kovács. 2008. Environmental, Social and Governance Key Performance Indicators from A Capital Market Perspective. Zeitschrift für Wirtschafts- und Unternehmensethik, 9(2) 182-192.

Belz, Thomas, et al. 2018. Taxes and Firm Size: Political Cost or Political Power? Journal of Accounting Literature, 42(Juni 2009), $1-28$.

Bonsón, Enrique \& Michaela Bednárová. 2015. CSR Reporting Practices of Eurozone Companies. Revista de Contabilidad, 18(2): 182-193.

The Cadbury Committee. 1992. The Report On the Financial Aspects of Corporate Governance. London: Gee and Co. Ltd. https://ecgi. global/code/cadbury-report-financial-aspects-corporate-governance

Cahyaningsih \& Venti Yustianti Martina. 2011. Pengaruh Mekanisme Corporate Governance dan Karakteristik Perusahaan terhadap Pengungkapan Tanggungjawab Sosial. Jurnal Siasat Bisnis, 15(2), 171-186.

Elfeky, Mostafa I. 2017. The Extent of Voluntary Disclosure And Its Determinants In Emerging Markets: Evidence From Egypt. The Journal of Finance and Data Science, 3(1-4), 45-59.

Frendy \& Indra Wijaya Kusuma. 2011. The Impact of Financial, Non-Financial, and Corporate Governance Attributes on the Practice of Global Reporting Initiative (GRI) Based Environmental Disclosure. Gadjah Mada International Journal of Business, 13(2), 143-159.

Giannarakis, Grigoris. 2014. The Determinants Influencing the Extent of CSR Disclosure. International Journal of Law and Management, 56(5), 393-416.

Goh, Beng Wee, et al. 2016. The Effect of Board Independence on Information Asymmetry. European Accounting Review, 25(1), 155182 .

Hackston, David \& Markus J. Milne. 1996. Some Determinants of Social and Environmental Disclosures In New Zealand Companies. Accounting, Auditing \& Accountability Journal, 9(1): 77-108.

Kumar, Tapos. "Achieving Sustainable Development through Environment Accounting from the Global Perspective: Evidence from Bangladesh.” Asian Journal of Accounting Research 2.1 (2012), 45-61. 
Luhn, A., Aslanyan, S., Leopoldseder, Ch.. Priess, P. 2017. An evaluation of knowledge management system's components and its financial and non-financial implications, Entrepreneurship and Sustainability Issues, 5(2), 315-329. http://doi.org/10.9770/jesi.2017.5.2(11)

Mitchell, Ronald K. 1997. Toward a Theory of Stakeholder Identification and Salience: Defining the Principle of Who and What Really Counts. The Academy of Management Review, 22(4), 853-886.

Mayorova, E. 2019. Corporate social responsibility disclosure: evidence from the European retail sector. Entrepreneurship and Sustainability Issues, 7(2), 891- 905. http://doi.org/10.9770/jesi.2019.7.2(7)

Mukhlis, Imam. 2009. Eksternalitas, Pertumbuhan Ekonomi dan Pembangunan Berkelanjutan dalam Perspektif Teoritis. Jurnal Ekonomi Bisnis, 14(3), 193-199.

Narkunienè, J., Ulbinaitè, A. 2018. Comparative analysis of company performance evaluation methods. Entrepreneurship and Sustainability Issues, 6(1), 125-138. http://doi.org/10.9770/jesi.2018.6.1(10)

Nasih, M., Harymawan, I., Paramitasari, Y., \& Handayani, A. (2019). Carbon Emissions, Firm Size, and Corporate Governance Structure: Evidence from the Mining and Agricultural Industries in Indonesia. Sustainability. 11.

Nasution, Ryan Muhammad \& Desi Adhariani. 2016. Simbolis atau Substantif? Analisis Praktik Pelaporan CSR dan Kualitas Pengungkapan. Jurnal Akuntansi dan Keuangan Indonesia, 13(1), 23-51.

OECD. 2015. G20/OECD Principles of Corporate Governance. Paris: OECD Publishing. http://dx.doi.org/10.1787/9789264236882-en

Razeed, Abdul. Determinants of Environmental Disclosure Practices of US Resource Companies: Hard Copy Versus Internet Reporting. Disampaikan dalam Sixth Asia Pacific Interdisciplinary Research in Accounting Conference, Sydney, New South Wales, July 12, 2010. http://apira2010.econ.usyd.edu.au/conference_proceedings/

Slaper, Timothy F. \& Tanya J. Hall. 2011. The Triple Bottom Line: What Is It and How Does It Work?. Indiana Business Review, 86(1): 4-8.

Solikhah, Badingatus \& Arga Mustika Winarsih. 2016. Pengaruh Liputan Media, Kepekaan Industri, dan Struktur Tata Kelola Perusahaan Terhadap Kualitas Pengungkapan Lingkungan. Jurnal Akuntansi dan Keuangan Indonesia, 13(1), 1-22.

Suaryana, Agung. 2011. Implementasi Akuntansi Sosial dan Lingkungan di Indonesia. Jurnal Ilmiah Akuntansi dan Bisnis, 6(1).

Narkunienè, J., Ulbinaite, A. (2018). Comparative analysis of company performance evaluation methods. Entrepreneurship and Sustainability Issues, 6(1), 125-138. http://doi.org/10.9770/jesi.2018.6.1(10)

Subačienè, R., Alver, L., Brūna, I., Hladika, M., Mokošová, D., Molín, J. 2018. Evaluation of accounting regulation evolution in selected countries. Entrepreneurship and Sustainability Issues, 6(1), 139-175. http://doi.org/10.9770/jesi.2018.6.1(11)

Sutopo, Yeri \& Achmad Slamet. 2017. Statistika Inferensial, ed. 1. Yogyakarta: ANDI.

UNFCCC. Biennial Reports Data Interface (BR-DI). Diakses dari https://www4.unfccc.int/sites/br-di/Pages/Home.aspx

United Nations. 1997. United Nations Conference on Environment and Development (1992). Department of Public Information. Diakses dari https://www.un.org/geninfo/bp/enviro.html

Voorn, Bart, et al. 2019. Multiple Principals, Multiple Problems: Implications for Effective Governance and A Research Agenda for Joint Service Delivery. Public Administration, 2019, 1-15.

Widyadmono, V. Mardi. 2014. The Impact of Type of Industry, Company Size and Leverage on the Disclosure of Corporate Social Responsibility Case on Companies Listed in Indonesia Stock Exchange 2009-2012. Jurnal Siasat Bisnis, 18(1), 118-132.

Yin, Juelin, et al. 2013. Stakeholder Perspectives on Corporate Social Responsibility (CSR) of Multinational Companies in China. Journal of International Business Ethics, 6(1), 57-71.

Zulkafli, Abdul Hadi, et al. 2017. The Performance of Socially Responsible Investments in Indonesia: A Study of the Sri Kehati Index (SKI). Gadjah Mada International Journal of Business, 19(1), 59-76.

Keputusan Direksi PT Bursa Efek Jakarta.

Peraturan Otoritas Jasa Keuangan.

Peraturan Presiden Republik Indonesia

Surat Edaran Otoritas Jasa Keuangan.

Undang-Undang Republik Indonesia. 


\section{Aknowledgements}

The authors would like to thank the editor and anonymous reviewers for their supportive comments and suggestions. The authors have received partial funding for this research from Universitas Airlangga Research Grant.

Short biographical note about the contributors at the end of the article (name, surname, academic title and scientific degree, duties, research interests):

Mohammad NASIH is a Professor and also a Lecturer of Universitas Airlangga, Indonesia. His current research focuses include financial accounting and Islamic accounting.

Khusnul PRASETYO is a Lecturer of Universitas Airlangga, Indonesia. His current research focuses include financial accounting, management accounting, and cost accounting.

Ekanto Ardi RAMADHAN is a student at the Department of Accounting, Universitas Airlangga.

Tubagus Algan ROISTON is a master student at the Department of Accounting, Universitas Airlangga.

Eka Sari AYUNINGTYAS is a master student at the Department of Accounting, Universitas Airlangga. 